\title{
Effect of Stilbene Resveratrol on Haematological Indices of Rats
}

\author{
J. DOUBEK, T. VOLNÝ1 ${ }^{1}$, A. LOJEK², Z. KNOTKOVÁ, V. KOTRBÁČEK, \\ P. SCHEER, Z. HOLEŠOVSKÁ \\ University of Veterinary and Pharmaceutical Sciences, Brno, Institute of Physiology, Czech Republic \\ ${ }^{1}$ Favea s.r.o., Kopřivnice, Czech Republic \\ 2 Institute of Biophysics of Academy of Sciences, Brno, Czech Republic \\ Received September 8, 2004 \\ Accepted June 6, 2005
}

\begin{abstract}
Doubek J., T. Volný, A. Lojek, Z. Knotková, V. Kotrbáček, P. Scheer, Z. Holešovská: Effect of Stilbene Resveratrol on Haematological Indices of Rats. Acta Vet. Brno 2005, 74: 205-208.

The objective of this study was to find whether the short-time intake of stilbene-resveratrol can influence some haematological indices. The tested compound extracted from the fleeceflower knotweed (Polygonum cuspidatum) was dissolved in saline and administered by a gastric cannula to 15 experimental male rats of Wistar outbreeeding for a week at a daily dose of $4 \mathrm{mg} / \mathrm{kg}^{0.75}$ of body weight. The effects of resveratrol were compared with 15 control rats that received saline in the same way. The SPF rats (Anlab, Prague) were kept individually in cages and were provided with drinking water and complete feed mixture "Biostan Mypo" ad libitum. The feed contained all necessary energy nutrients, vitamins and minerals for the given animal species and their age. Using a colorimetric method and the Griess agent plasma concentrations of nitrites were determined in blood samples taken at the end of experimental period. Total antioxidative capacity (TRAP) of blood was determined luminometrically and using the aggregometer APACT II employing the turbidimetric method by Born functional tests of platelets were performed. ADP and collagen were employed to induce aggregation. Resveratrol administration did not influence plasma nitrites. No changes were observed in total antioxidative capacity of blood and aggregation characteristics of platelets. However, platelet disaggregation was significantly enhanced $(p<0.01)$ and their counts significantly decreased $(p<0.01)$. The results indicate that parameters important for haemostasis can be influenced by the short-time intake of resveratrol administered at the given dose.
\end{abstract}

Antioxidative capacity, platelets, platelet aggregation, disaggregation, plasma nitrites

Resveratrol (trans-3, 5, 4'-trihydroxystilbene) is a plant phenolic compound that enters the food chain of humans and animals. In humans, its intake is associated with the consumption of wine, especially red wine. The so-called French paradox is often mentioned in this context: low occurrence of cardiovascular diseases in France, where daily consumption of wine has a long tradition (Renaud and De Lorgeni 1992). The animals, mainly herbivores, are assumed to take it up in vegetable food because it is not contained in grapevine only. About 70 plant species contain this compound. The content of resveratrol is high e.g. in knotweed (Polygonum) and in false hellebore (Veratrum) (Bertelli et al. 1996). Resveratrol is reported to have significant antioxidative (Fuhmar et al. 1996; Belguend ouz et al. 1997), anti-inflammatory (Kimura et al. 1995) and anticoagulating effects (Bertelli et al. 1995, 1999) in the organism. It also promotes the biosynthesis of NO and as such has cardioprotective effects (Hsieh et al. 1999).

Our experiments on rats were conducted to determine the effect of resveratrol on total antioxidative capacity of blood, plasma $\mathrm{NO}_{2}^{-}$as an indicator of production of the important vasodilating substance - NO, and counts of platelets and their functional changes.

\section{Materials and Methods}

Experiments were conducted with two groups of male rats of Wistar stock originating in SPF breeds (Anlab,

Address for correspondence:

Prof. MVDr. Jaroslav Doubek, CSc.

University of Veterinary and Pharmaceutical Sciences

Palackeho 1-3

61242 Brno, Czech Republic

Phone: +420 541562226

E-mail: doubekj@vfu.cz

http://www.vfu.cz/acta-vet/actavet.htm 
Prague). Each group comprised 15 rats. They were kept individually in cages and provided with drinking water and complete feed mixture "Biostan Mypo" ad libitum. The feed contained all necessary energy nutrients, vitamins and minerals for the animal species and age. After three weeks of adaptation to the testing conditions rats were examined clinically and then included in the experiment. Resveratrol was administered to 15 adult rats through a gastric cannula under ether anaesthesia (Hes s et al. 1984). Micronised, crystalline resveratrol extracted from roots of the fleeceflower knotweed (Polygonum cuspidatum) was prepared so as to produce a standard of constant effective substance concentration. The dry extract was dissolved in physiological saline and administered at a dose of $4 \mathrm{mg}$ resveratrol $/ \mathrm{kg}^{0.75}$ body mass.

Fifteen control rats were given physiological saline in the same way. Resveratrol and saline were administered once a day for a week. Blood samples for the determination of $\mathrm{NO}_{2}^{-}$and total antioxidative capacity of blood (TRAP) were taken at the mid-week and at the end of the week, when blood was also collected to determine platelet activity. Blood was collected by cardiac puncture under anaesthesia. In order to determine $\mathrm{NO}_{2}^{-}$and TRAP a total of $1 \mathrm{ml}$ of blood was collected using citrate as anticoagulant agent. To examine platelets $5 \mathrm{ml}$ of blood were collected using heparin as anticoagulant. Animals were then euthanised by bleeding. Concentrations of both nitrites and nitrates were measured as an indicator of NO production according to Gilliam et al. (1993). Plasma nitrates were reduced to nitrites using nitrate reductase (Sigma, USA). Then total concentration of nitrites $\left(\mathrm{NO}_{2}^{-}\right)$in plasma was determined colorimetrically with Griess reagent (Sigma, USA). The absorbance was measured at $546 \mathrm{~nm}$ (Spectra Rainbow, SLT, Austria). Sodium nitrite was used as a standard. Total numbers of platelets were determined using the blood analyser CELLDINE 1700 (Abbot, Il, USA). A functional test of platelets was employed to determine their aggregation and subsequent disaggregation. Aggregometer APACT II employing the turbidimetric method by Born was used. It is based on changes in light passage through an aggregometer that occur during the formation of platelet aggregates. Collagen and ADP were used to induce aggregation. Platelet disaggregation was expressed as a percentage proportion in maximum values of aggregation curve.

The Ethics Committee of Faculty of Veterinary Medicine, University of Veterinary and Pharmaceutical Sciences Brno, approved this study.

Results were evaluated using the Student's $t$-test.

\section{Results and Discussion}

No significant differences were found in plasma $\mathrm{NO}^{-2}$ concentrations and in the values of total radical antioxidant parameter of blood between the experimental and control rats (Figs 1 and 2). Contrary to expectations, TRAP did not increase, not even after a one-week administration of resveratrol to rats. However, the total result admits a possibility of changes in the values of particular antioxidants and in their share in this summary value (Nieto et al. 2002).

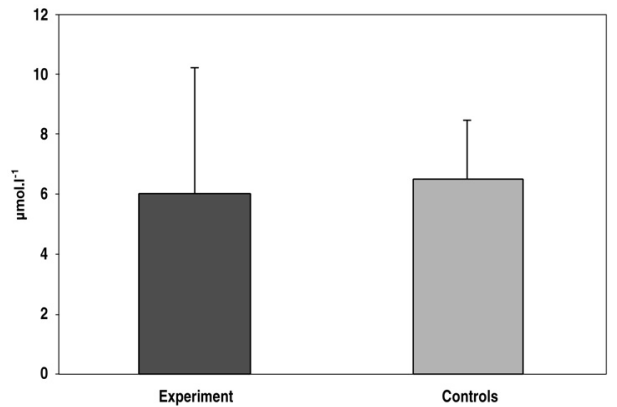

Fig. 1. Effect of resveratrol on plasma $\mathrm{NO}_{2}^{-}$concentration

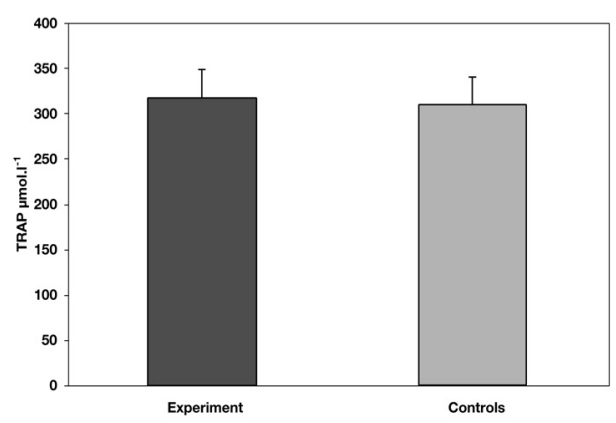

Fig. 2. Effect of resveratrol on TRAP of blood

(Krajcovicova-Kudlacova et al. 2002) stated that the summary result did not have to change even though the values of some antioxidants increased substantially. The authors explained it as a consequence of the dominant position of uric acid in the antioxidative system, which may overlap with changes in its other components. Contrary to findings from long-term experiments conducted by Bertelli et al. $(1995,1998)$ the platelet aggregation did not decrease in our rats (Fig. 3). Their disaggregation increased significantly $(p<0.01)$ 
(Fig. 4); it was in agreement with the described "aspirin effect" of resveratrol. The effect of administered resveratrol on platelets was also confirmed by data on their counts that decreased in experimental individuals significantly $(p<0.01)$ (Fig. 5).

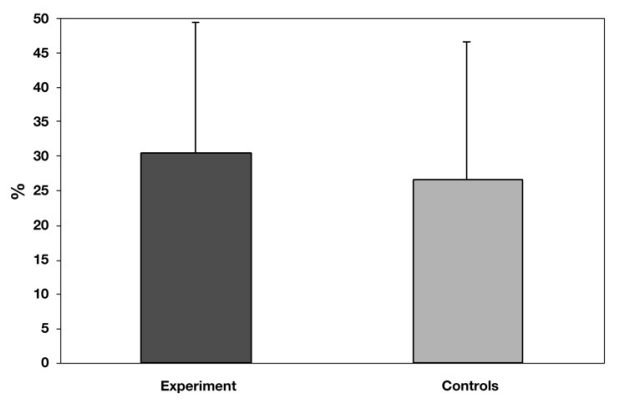

Fig. 3. Effect of resveratrol on platelet aggregation

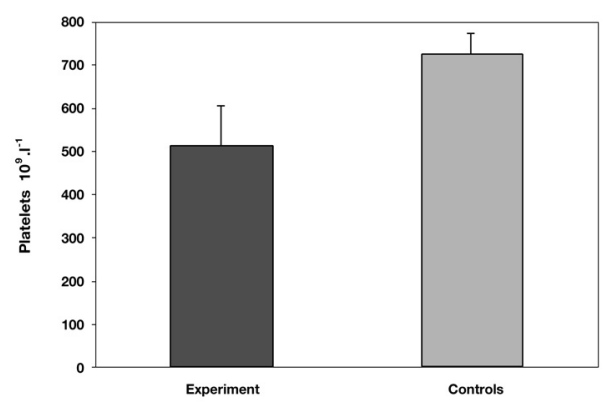

Fig. 5. Platelet counts

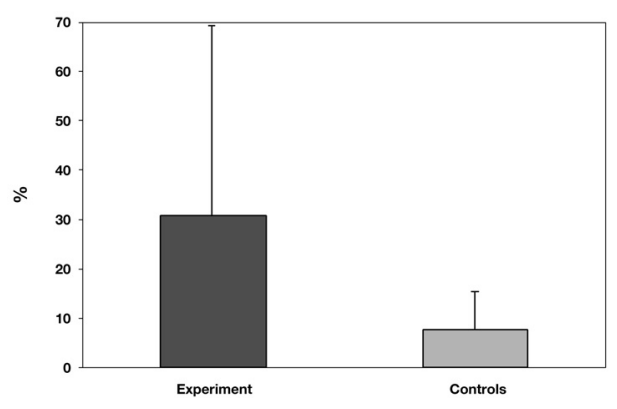

Fig. 4. Effect of resveratrol platelet disaggregation

Even though the weekly administration did not have the expected effect on some investigated indices, a conclusion can be drawn that this short-time intake significantly influenced two parameters that are not less important: counts of platelets and their functional characteristics which can be better assessed using the ADP. In conclusion, resveratrol extracted from the fleeceflower knotweed (Polygonum cuspidatum) and administered to rats at a dose of $4 \mathrm{mg} / \mathrm{kg}^{0.75}$ daily for a week did not influence the content of nitrites - indirect indicator of the production of an important vasodilator - nitric oxide. TRAP values were not influenced either. Resveratrol administration significantly reduced platelet counts and increased their disaggregation after ADP-induced aggregation.

\section{Vliv stilbenu - resveratrolu na vybrané hematologické parametry potkanů}

Cílem práce bylo zjistit, zda krátkodobý př́ijem stilbenu - resveratrolu může ovlivnit vybrané hematologické parametry. Testovaná látka extrahovaná z rdesna (Polygonum cuspidatum) byla rozpuštěna ve fyziologickém roztoku $\mathrm{NaCl}$ a žaludeční sondou týden podávána 15 outbredních pokusným potkanům v denní dávce $4 \mathrm{mg} / \mathrm{kg}^{0,75}$ hmotnosti potkana. Účinnost resveratrolu byla porovnána s 15 kontrolními jedinci, kterým byl stejným postupem podáván fyziologický roztok. V odebraných vzorcích krve kardiální punkcí byla kolorimetricky, s použitím Griessova činidla, zjištována plazmatická koncentrace nitritů. Luminometricky byla zjištována celková antioxidační kapacita krve a pomocí agregometru APACT II využívající Bornovu turbidimetrickou metodu byly provedeny funkční testy trombocytů. Jako induktory agregace byly použity ADP a kolagen. Analyzátorem krevního obrazu CELLDINE 1700 byly dále stanoveny počty trombocytů. Podávání resveratrolu neovlivnilo hladinu nitritů. Nezměnila se ani celková antioxidační kapacita krve a agregační vlastnosti trombocytů. Desagregační schopnost 
trombocytů se po předchozí agregaci ADP průkazně zvýšila $(p<0,01)$ a významně klesly i počty krevních destiček $(p<0,01)$.

Z výsledků vyplývá, že i krátkodobý př́jem resveratrolu může v uvedených dávkách ovlivňovat funkce významné v hemostatických procesech.

\section{References}

BELGUENDOUZ L, FREMONT L, LINARD A 1997: Resveratrol inhibits metal ion-dependent and independent peroxidation of porcine low density lipoproteins. Biochem Pharmacol 53: 1347-1353

BERTELLI A, BERTELLI AA, GOZZINI A, GIOVANNINI L 1998: Plasma and tissue resveratrol concentrations and pharmacological activity. Drug Exp Clin Res 24: 133-138

BERTELLI AA, FERRARA F, DIANA G, FULGENZI A, CORZI M, PONTI W, FERRERO ME, BERTELLI A 1999: Resveratrol a natural stilbene in grapes and wine, enhances intraphagocytosis in human promonocytes: a co-factor in antiinflammatory and anticancer chemopreventive activity. Int J Tissue React 21: 93-104

BERTELLI AA, GIOVANNINI L, GLANNESSI D 1995: Antiplatelet activity of synthetic and natural resveratrol in red wine. Int J Tissue React 17: 1-10

BERTELLI AA, GIOVANNINI L, STRADI R, BERTELLI A, TILLEMENT JP 1996: Plasma, urine and tissue levels of trans- and cis-resveratrol (3, 4, 5-trihydroxystilbene) after short-term or prolonged administration of red wine to rats. Int J Tissue React 18: 67-71

FUHMAR S, LAVY A, AVIRAM M 1996: Consumption of red wine with meal reduced the susceptibility of human plasma and low-density lipoprotein to lipid peroxidation. Am J Clin Nutr 81: 549-554

GILLIAM MB, SHERMAN MP, GRISCAVAGE JM, IGNARRO LJ 1993: A spectrophotometric assay for nitrate using NADPH oxidation by Aspergillus nitrate reductase. Anal Biochem 212: 359-365

HESS L, DVOŘÁČEK J, SVOBODNÍK J 1984: Anestezie laboratorních zvířat. Avicenum Praha, 256 p.

HSIEH TC JUAN G, DARZYNKIEWICZ Z, WU JM 1999: Resveratrol increases nitric oxide synthase, induces accumulation of $\mathrm{p} 53$ and $\mathrm{p} 21$ (WAF $1 / \mathrm{C} / \mathrm{P} 1)$ and supresses cultured bovine pulmonary artery endothelial cell proliferation by perturbing progression through $\mathrm{S}$ and G2. Cancer Res: 59: 2557-2561

KIMURA Y, OKUDA H, KUBO M 1995: Effects of stilbenes isolated from medical plants on arachidonate metabolism and degranulation in human polymorphonuclear leukocytes. J Ethnopharmacol: 45: 131-139

KRAJCOVICOVA-KUDLACOVA M, HUDECOVA Z, PAUKOVA V, VOLKOVOVA K, STARUCHOVA M 2002: Antioxidative plasma capacity from aspect of nutrition. Hygiena 47: 90-96

NIETO FJ, IRIBARREN C, GROSS MD, COMSTOCK GW, CUTLER RG 2000: Uric acid and serum antioxidant capacity a reaction to atherosclerosis? Atherosclerosis 148: 131-139

RENAUD S, DE LORGENI M 1992: Wine alcohol, platelets and the French paradox for coronary heart disease. Lancet 339: 1523-1528 